Andrzej KOMPOWSKI, Wiesław ŚLÓSARCZYK

Fish biology

\title{
BIOLOGICAL CHARACTERISTIC OF POLISH CATCHES \\ OF THE HORSE MACKEREL - TRACHURUS TRACHURUS CAPENSIS CASTELNAU, 1861 IN THE REGION OF THE SOUTH-WEST AFRICAN SHELF BIOLOGICZNA CHARAKTERYSTYKA POLSKICH POLOWÓW OSTROBOKA POSPOLITEGO TRACHURUS TRACHURUS CAPENSIS CASTELNAU, 1861 W REJONIE SZELFU POKUDNIOWO-ZACHODNIEJ AFRYKI
}

\author{
Institute of Ichthyology, Szczecin \\ Sea Fisheries Institute, Gdynia
}

This paper contains a short estimate of catches with regard to the yield and specific composition shown against the background of occuring depths and water temperatures; it presents results of the analysis of length and age composition as well as those of growth and mortality of the horse mackerel. Further chapters contain the results of food analysis and the gonad's state of this species.

\section{INTRODUCTION}

The horse mackerel like the hake and the sardinops plays a great part in the fisheries in the south-west areas of the African shelf. This great importance of the horse mackerel in this region; already recorded in the 50-ties, has presently still increased (Davies, 1957; AtlantNIRO, 1974). In 1973, in the catches of Polish trawlers type - B-23 it made the main bulk of all fish caught. In spite of an intensive exploitation by the fisheries of different countries, the horse mackerel biology is still not well known. The authorities of the I.C.S.E.A.F. fishing convention recommend the intensification of studies in this field.

The scope of this paper is to enlarge the resources of knowledge of this subspecies. 


\section{MATERIAL AND METH@DS}

The studies contained in this paper have been conducted on the material collected by the authors on Polish freezer -- trawlers type B-23, which from 2 June to 11 October 1973 were operating in the region of the south-west African shelf.

The kind of biological material collected for these investigations as well as the survey of the analysis is shown in Table I. The geographical position of those fishing grounds

Table 1

Number of analysis performed

\begin{tabular}{|l|c|c|c|c|c|}
\hline \multirow{2}{*}{$\begin{array}{c}\text { fishing } \\
\text { ground }\end{array}$} & \multirow{2}{*}{$\begin{array}{c}\text { Period of } \\
\text { investigation }\end{array}$} & $\begin{array}{c}\text { length me- } \\
\text { asurement }\end{array}$ & $\begin{array}{c}\text { age deter- } \\
\text { mination }\end{array}$ & $\begin{array}{c}\text { gonads' } \\
\text { state }\end{array}$ & $\begin{array}{c}\text { food } \\
\text { analysis }\end{array}$ \\
\hline $\begin{array}{l}\text { Cape Frio - } \\
\text { Cunene River } \\
16^{\circ} 50^{\prime}-18^{\circ} 47^{\prime} \mathrm{S}\end{array}$ & $1-11 . \mathrm{X}$ & 2839 & 255 & 253 & 128 \\
\hline $\begin{array}{l}\text { Ambrose Bay } \\
20^{\circ} 35^{\prime}-22^{\circ} 05^{\prime} \mathrm{S}\end{array}$ & 11. VII-30.IX & 2127 & 72 & 198 & 21 \\
\hline $\begin{array}{l}\text { Cape Cross } \\
22^{\circ} 10^{\prime}-22^{\circ} 40^{\prime} \mathrm{S}\end{array}$ & $2-17 . \mathrm{VI}$ & 1212 & 55 & 157 & 53 \\
\hline $\begin{array}{l}\text { Lüderitz } \\
25^{\circ} 15^{\prime}-26^{\circ} 20^{\prime} \mathrm{S}\end{array}$ & $19 . \mathrm{VI}-6 . \mathrm{VIII}$ & 272 & 152 & 146 & 147 \\
\hline Total number & & 6450 & 534 & 754 & 350 \\
\hline
\end{tabular}

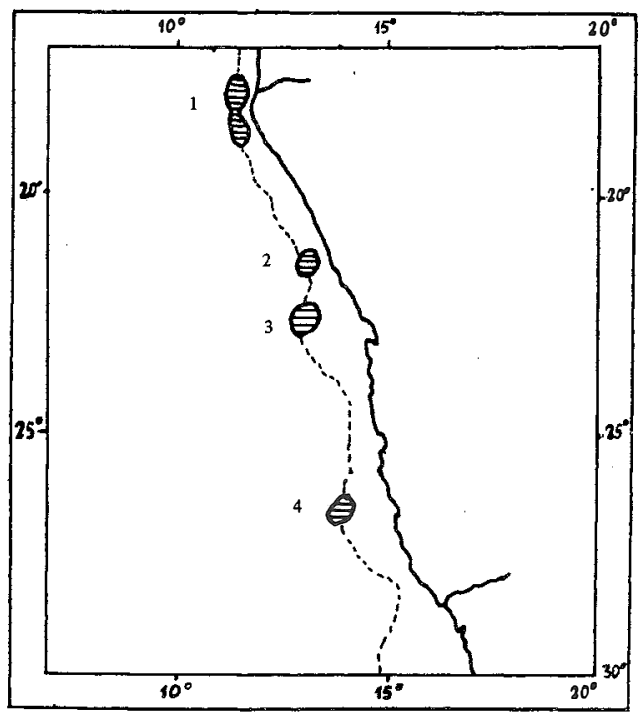

Fig. 1. Sites from which horse mackerel samples were taken. 1. Cape Frio - Cunene River, 2. Ambrose Bay, '. Cape Cross, 4. Luderitz. 
from which the samples were collected is presented in Fig. '. This material has been processed according to the standard method accepted in the investigations conducted for the I.C.S.E.A.F. convention. Total length (l.t.) of fish was measured with the accuracy of $1 \mathrm{~cm}$, to the lower value; the state of gonads is denoted according to the simplified five-degree scale; I - juvenile stage, II resting stage, III developing stage, IV ripening stage, $\mathrm{V}$ - spent stage.

Age has been determined by counting a number of hyaline zones on the otoliths. After Marecos (1974) it has been accepted that one opaque zone and a contiguous hyaline zone form once a year. For food analysis the weight method was used.

\section{CATCHES}

The fishing region was stretching from the estuary of the Cunene River up to the port of Lüderitz (Fig. 1).

Cape Frio - Cunene River. The observations in this region were made in the first half of October. The horse mackerel was the prevailing species and made $85 \%$ of the catches. In the bottom hauls there was Dentex macrophthalmus mainly and in the pelagic hauls Scomber colias and Sardinops ocellata. The yield reached up to 15 tons/hr. The depth of the fishing ground was $110160 \mathrm{~m}$.

Ambrose Bay. In this region fishing took place in July, August and September with the bottom trawl at the bottom depth of $125-130 \mathrm{~m}$, and alsu with a pelagic trawl in the water layer of $65-90 \mathrm{~m}$. The yield in this fishing ground was very high about 5 tons $/ \mathrm{hr}$ of haul. The maximal catch per hour of an effective trawling in the mid of July amounted up to 60 tons. In bottom travling the obtained yield was much higher. The predominating species was the horse mackerel which made $86 \%$ of çaught fish. There was a great number of small fish $16-20 \mathrm{~cm}$. In pelagic hauls there was also sardinops present and made $10 \%$ of fish mass. A large number of jellyfish accompanying groups of juvenile horse mackerel and sardinops made fishing difficult.

Cape Cross. In this region fishing lasted in the period fo 217 June, the depth of the fishing ground being $190260 \mathrm{~m}$. In the bottom layer mainly the horse mackerel was caught and made $80 \%$ of all fish. In a few pelagic hauls at the layer of $3570 \mathrm{~m}$ there was the colias mackerel present making $14 \%$ of the catch. The maximal yield in this fishing ground reached about $10,5 \mathrm{t} / \mathrm{hr}$ and the mean yield was on the level of $2.2 \mathrm{t}$.

Luideritz. In the period of investigation $(19.06$ 6.07) in this region there was mainly the hake caught ( $98 \%$ of the catch). However, there was also a big specimen of the horse mackerel caught, which then was analysed. The fishing depths in these area were much higher (350 $400 \mathrm{~m}$ ) than in other fishing grounds.

The highest yield in horse mackerel fishing was obtained at day time when the fish made bottom concentrations. At night, fish was scattered above the bottom and did not make close concentration. However, there were exceptions to this rule associated with 24-hour vertical migration of the horse mackerel and then on one hand night close bottom concentration could be observed, and on the other the fish was scattered in so called echo records. Such situation was the cause of an irregular yield. 
The relationship between the horse mackerel yield and the water temperature in the trawling layer is shown in Fig. 2.*
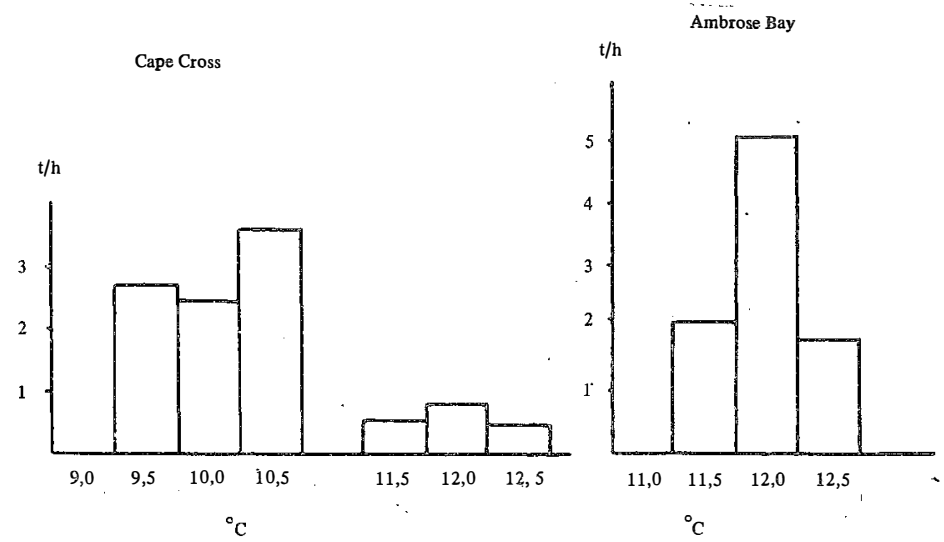

Fig. 2. Relationship between water temperature in the layer of trawling and catch yield of horse mackerel

In the Cape Cross fishing grounds this species was observed in a wide range of temperatures $9.25-12.75^{\circ} \mathrm{C}$. Higher water temperatures have been recorded at pelagic catches $11.5^{\circ} \mathrm{C}-12.75^{\circ}$ the trawling level being $110-50 \mathrm{~m}$. Because of their low yield only a few pelagic hauls were done (the yield being $0.5-0.8 \mathrm{t} / \mathrm{hr}$ of a haul). The majority of hauls were done at the bottom layer at $9.5-10.75^{\circ} \mathrm{C}$. In this water layer the yield was much higher.

Water temperatures at which horse mackerel was caught in the fishing grounds of the Ambrose Bay were the same as the temperatures at pelagic catches in the Cape Cross fishing grounds. However, in the first above mentioned-fishing ground the hauls were done at the bottom layer and the yield was much higher than that of the Cape Cross region, although the range of water temperatures was the same. The highest yield in the Ambrose Bay region was obtained at $12^{\circ} \mathrm{C}$.

An interesting phenomenon have been noticed, namely in the region of jellyfish mass occurrence there were juvenile fish present. In pelagic waters where there is no shelter this phenomenon is associated with the juveniles seeking shelter under the bells of the jellyfish during an intensive insolation. There, under the bells of this living shelter the juvenile fish are difficult to notice and inaccessible to any possible enemy. This specific kind of intercourse have been observed many a-time also in different regions and with many species of fish.

*Water temperature measurements were done with the "Elac" thermoprobe placed in the net 


\section{LENGTH, AGE, GROWTH AND MORTALITY}

In the catches conducted in the region stretching from the Cape Frio to the estuary of the Cunene River in the first decade of October the fish were of rather equal length. $22-26 \mathrm{~cm}$, the modal value being on the level of $24 \mathrm{~cm}$. There were specimen belonging to III age group (Fig.3). Apart from them there were rarely found large specimen of $40-48 \mathrm{~cm}$. Because of their big size in some of the hauls, they made up to $5 \%$ of the caught fish.

In the Ambrose Bay there were specimen of a wide range of length from 14-37 cm. The length distribution curve for the first period of fishing, that is the second decade of July, in this region has three peaks at $17-18,29$ and $33 \mathrm{~cm}$. Unfortunately, there is a lack of otoliths analyse for this period. In the period lasting from the end of July to the last decade of September the composition of catches in the respect of length was a bit different. The first peak of Petersen's curve was represented, like in the previous period, by small fish of the modal length of about $18 \mathrm{~cm}$. The second peak which did not occure previously was at about $23-24 \mathrm{~cm}$, and the third one was for fish of $28 \mathrm{~cm}$ of length. These peaks belong to the fish from II, III and IV age group subsequently (Fig. 3). In this period the peak on the level of $33 \mathrm{~cm}$ did not occure.

In the Cape Cross regions occured large specimen of the horse mackerel species, the length of which was $22-42 \mathrm{~cm}$. On the length distribution curve there were few clearly seen peaks, the first formed by the fish of $29 \mathrm{~cm}$, the second higher one formed by the fish of about $33 \mathrm{~cm}$. The analyse of the otoliths structure proved, that the fish which formed the first peak usually possessed four hyaline zones (IV age group) - Fig. 3.

Length composition of the catches from the Luideritz region was much like that of the previously discussed area, with the difference that the predominating fish were of $29 \mathrm{~cm}$. of modal length and the second peak equaling the fish of $33 \mathrm{~cm}$ was lower. Like in the case of the Cape Cross these peaks correspond to the fish from IV and V age group (Fig. 3).

As it results from the above description, the length as well as the age composition of the horse mackerel change considerably depending on the place of fishing. However, characteristic is the fact that no matter what the fishing place is the modal values more or less fall at the same lengths - 17-18;23-24;29 and $33 \mathrm{~cm}$. As it results from the otoliths analyse, these lengths correspond to the fish from II, III, IV and V age group. Basing on the analyse of morphological features Komarov (1971) believes that the horse mackerel from the regions stretching from the estuary of the Cunene River to the Walvis Bay should be recognized as one biological unit (stock). Basing on this statement the average fish lengths in each particular group have been calculated for the whole investigated area jointly (Table 2). These lengths are very close to the results obtained by Lipskaja (1972) for the fish from the same region. Basing on the data from Table 2 the parameters of Bertalanffy's growth equation were estimated using the method of Beverton and Holt (1957). They are:

$$
\mathrm{L}_{\infty}=46.989 \mathrm{~cm} ; \mathrm{K}=0.2498 ; \mathrm{t}_{\mathrm{o}}=0.1837 \text { of year. }
$$



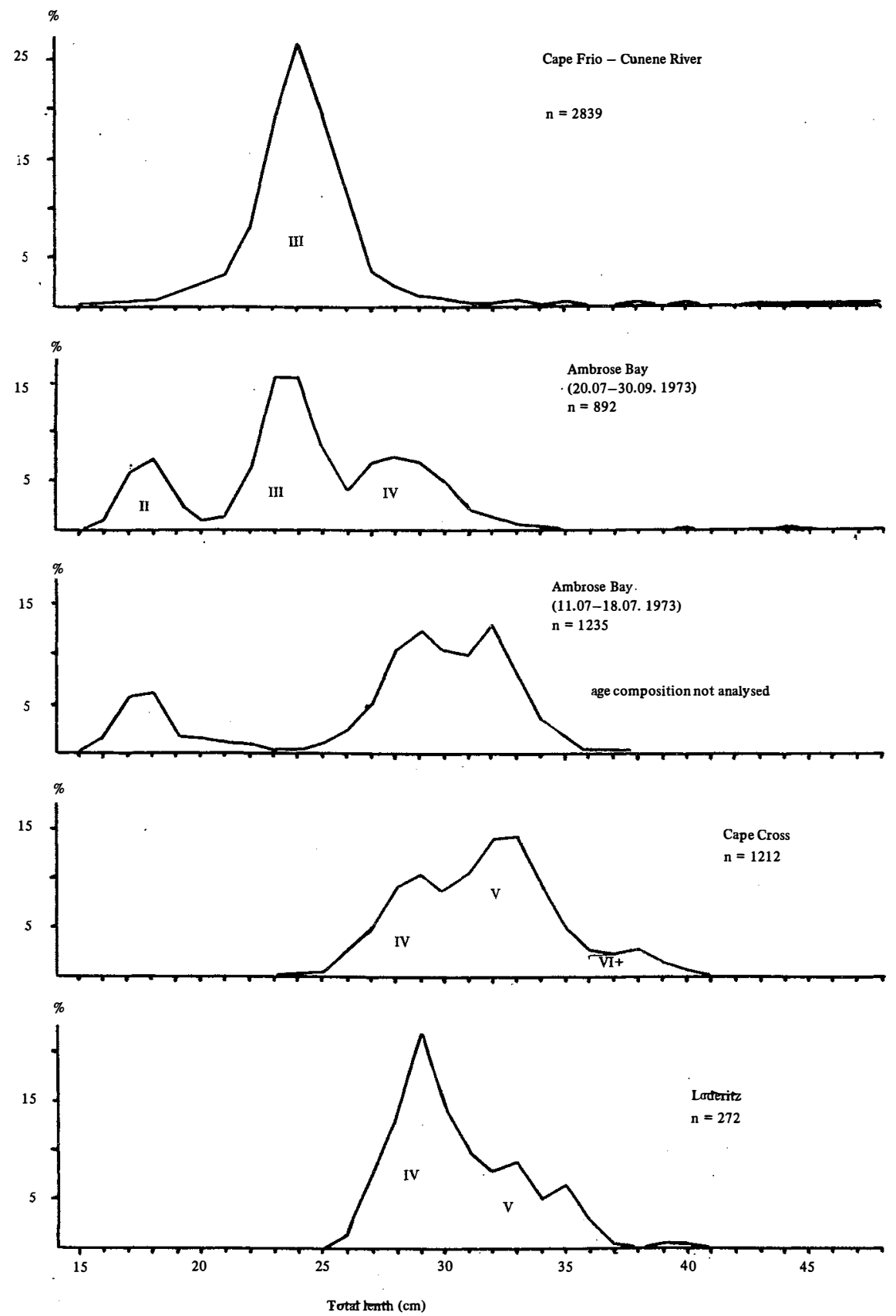

Fig. 3. Age composition of horse mackerel (Trachurus trachurus capensis Castelnau) 
Mèan lengths (1.t., cm) of the horse-mackerel

- Trachurs trachurs capensis Castelnau in particular age groups

\begin{tabular}{|c|c|c|c|c|c|c|c|c|c|}
\hline & \multicolumn{9}{|c|}{ Age groups } \\
\hline & I & II & III & IV & V & VI & VII & VIII & IX \\
\hline $\begin{array}{l}\text { Mean } \\
\text { lengths } \\
\text { acc. to } \\
\text { direct } \\
\text { measure- } \\
\text { ments }\end{array}$ & - & 17.5 & 24.5 & 28.7 & 32.8 & 35.0 & 38.5 & 40.5 & 41.9 \\
\hline range & - & $14-21$ & $20-29$ & $24-31$ & $28-36$ & $33-39$ & $35-43$ & - & - \\
\hline $\begin{array}{l}\text { Lengths } \\
\text { acc. to } \\
\text { von Ber- } \\
\text { talanffys } \\
\text { equation }\end{array}$ & 8.66 & 17.14 & 23.74 & 28.88 & 32.88 & 36.00 & 38.43 & 40.32 & 41.80 \\
\hline Number & - & 47 & 242 & $93^{\circ}$ & 98 & 28 & 4 & 2 & 3 \\
\hline
\end{tabular}

Theoretical lengths calculated with v. Bertalanffy's equation quite well agree with the empirical data (Table 2).

In Table 3 the frequency of horse mackerel belonging to particular age group in the catches of Polish trawlers is shown for the whole discussed area. It results from these data that nearly one half of the fish (46.6\%) belong to III age group and $36 \%$ of all examined fish belong to IV and $\mathrm{V}$ age group.

Total mortality coefficient " $\mathrm{z}$ " has been calculated basing on the catch curve using;

a) according to Jackson (after Ricker, 1958) the equation;

$$
\hat{S}=\frac{\mathbb{N}_{4}+N_{5} \ldots \ldots \ldots+\mathbb{N}_{n}}{N_{3}+N_{4} \ldots \ldots \ldots+N_{n-1}}=e^{-z}
$$

where: $\quad \mathrm{S}=$ survival coefficient

$\mathrm{N}_{\mathrm{n}}=$ a number of specimen in particular age groups

obtained $\mathrm{S}=0.44$, hence $\mathrm{z}=0.82$.

b) from the analyses of the slope of catch curve the equation of linear regression has been calculated

$$
\mathrm{y}=10.1-0.9 x
$$

hence $\mathrm{z}=0.9$

Natural mortality coefficient (M) has been estimatively determined to be on the level " of $0.25-0.5$; in accordance with Gulland's (1969) presumption for the dependence between $\mathrm{K}$ and $\mathrm{M}$ coefficient. When determining $\mathrm{M}$ there was the same ratio accepted as that for Clupeidae: 
$\mathrm{M}=1 \mathrm{~K}$ to $2 \mathrm{~K}$. In this way a considerably high fishing mortality,coefficient $(\mathrm{F})$ has been obtained on the following level;

a) 0.32 to 0.57 for calculations according to formula 1

b) 0.40 to 0.65 on the base of the catch curve analyses, that would prove that in the discussed area the horse mackerel stock is being under a big fishery pressure. However, these estimations should be treated as preliminary for they are solely based on the catches from a very short period of time June - October 1973, and also on the presumption of such $\mathrm{F}$ to $\mathrm{M}$ ratio like that for Clupeidae.

Table 3

Age composition of the horse-mackerel caught in the

Namibian shelf in July - October 1973 by Polish trawlers

\begin{tabular}{|l|c|c|c|c|c|c|c|c|c|c|}
\hline & \multicolumn{8}{|c|}{ Age groups } \\
\cline { 2 - 11 } & II & III & IV & V & VI & VII & VIII & IX & X+ & Total \\
\hline $\begin{array}{l}\text { Number calculated } \\
\text { into mass measurement }\end{array}$ & 205 & 1644 & 562 & 528 & 123 & 15 & 9 & 30 & 2 & 3118 \\
\hline$\%$ \%o & 65.7 & 527.4 & 180.4 & 169.3 & 39.4 & 4.8 & 2.9 & 9.5 & 0.6 & 1000,0 \\
\hline
\end{tabular}

It is worthwhile to pay more attention to the otoliths. On the edges of the otolith there was always an opaque zone formed and close behind it there was also a narrow or wider hyaline zone. The hyaline zone from the otolith's edge was better formed in younger fish. At the end of the discussed period, that is in September and in October, the hyaline zone was clearly formed in all fish from the Ambrose Bay fishing grounds and from the regions of the Cape Frio - Cunene River. According to Belan (1971) observations forming of the hyaline zones of the horse mackerel in the discussed area lasts the whole year round. The maximal per cent of fish with the hyaline zone formed he observed in October and in November, that is in the period very close to that observed by us. Thus, without counting the spawning period the period of hyaline zone development, that is July - August, can be accepted as horse mackerel birthday in this area. In order to obtain clear and uniform data all hyaline zones from the otolith's edge were taken under consideration at age determination, no matter whether fully or partially developed.

\section{STATE OF GONADS}

The state of gonads of the horse mackerel from each discussed area is shown in Table 4. In the fishing grounds of the Cape Cross and Lüderitz in June and at the beginning of July all fish were spent or had their gonads in a resting stage. In the region of the Ambrose Bay and the Cape Frio - Cunene River a great majority of sexually mature fish had gonads in the resting stage. Thus, the state of gonads proves that the above mentioned fish stocks were neither of pre-spawning or of spawning character. 
Table 4

Maturity state of gonads of the horse-mackerel from the areas of the Namibian shelf in July - October 1973 (according to'the simplified five-degree scale)

\begin{tabular}{|c|c|c|c|c|c|c|c|c|c|c|c|c|}
\hline \multirow{3}{*}{ Region } & \multicolumn{10}{|c|}{ Maturity stages of gonads } & \multirow{2}{*}{\multicolumn{2}{|c|}{ Total }} \\
\hline & \multicolumn{2}{|c|}{ I } & \multicolumn{2}{|c|}{ II } & \multicolumn{2}{|c|}{$\therefore$ III } & \multicolumn{2}{|c|}{ IV } & \multicolumn{2}{|c|}{ V } & & \\
\hline & $\mathrm{n}$ & $\%$ & $\mathrm{n}$ & $\%$ & $\mathrm{n}$ & $\%$ & $\mathrm{n}$ & $\%$ & $\mathrm{n}$ & $\%$ & $\mathrm{n}$ & $\%$ \\
\hline $\begin{array}{l}\text { Cape Frio - } \\
\text { Cunene } \\
\text { River }\end{array}$ & 1 & 0.4 & 239 & 94.5 & 11 & 4.3 & - & - & 2 & 0,8 & 253 & 100,0 \\
\hline $\begin{array}{l}\text { Ambrose } \\
\text { Bay }\end{array}$ & 69 & 34.7 & 89 & 45.0 & 29 & 14.7 & - & - & 11 & 5.6 & 198 & 100,0 \\
\hline $\begin{array}{l}\text { Cape } \\
\text { Cross }\end{array}$ & - & - & 75 & 47.8 & 29 & 18,5 & - . & - & 53 & 33.7 & 157 & 100,0 \\
\hline Luderitz & - & - & 82 & 56.1 & 4 & 2.8 & - & - & 60 & 41.1 & 146 & 100,0 \\
\hline
\end{tabular}

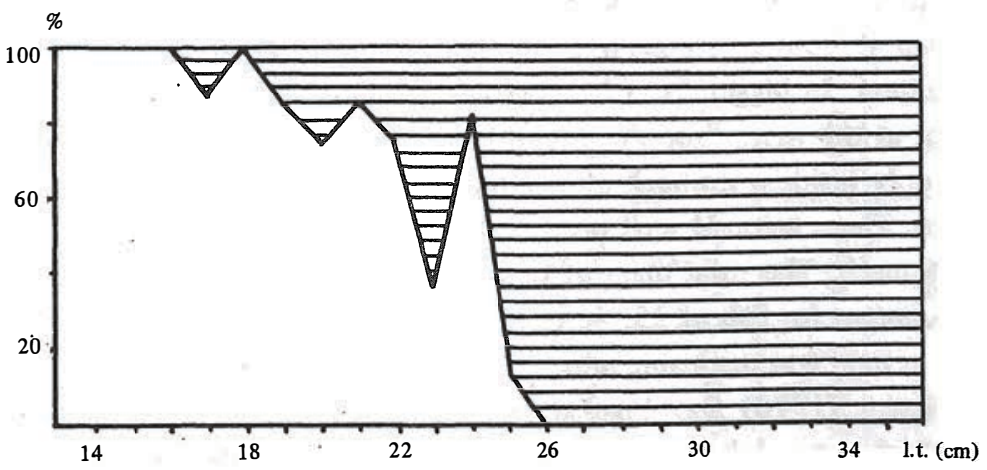

Fig. 4. Distribution in \% of immature (virgin) and mature fish in length classes of horse mackerel in Ambrose Bay.region (11.07-30.09. 1973)

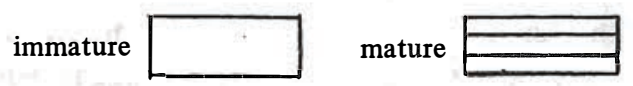

The process of getting sexually mature can be traced on the example of the Ambrose Bay fishing grounds. In order to illustrate this process specimen with I stage gonads, distinguished as immature were put into opposition with the specimen from II and III-IV stages recognized as mature (Fig. 4). Among the fish of $16 \mathrm{~cm}$ in length there were only immature specimen, and on the contrary, all fish of $26 \mathrm{~cm}$ or more were sexually mature. Thus, there are some individual deviations in length at which the horse mackerel achieves sexual maturity for the first time. According to Komarov (1964) the horse mackerel from the examined area achieves the first sexual maturity at the length of 22 to $27 \mathrm{~cm}$. 


\section{FOOD}

For food analysis only the stomach contents were used. The horse mackerel stomach is well separated from the rest of the alimentary tract. The occurrence of the fish scales, mainly those of horse mackerel, in majority of examined stomachs was an interesting phenomenon. These scales, the diameter of which was from 2-6 mm, were concentrated always in the anterior part of the stomach just behind the oesophagus. Very often the oesophagus was also filled with scales. The size of these scales equaled the average length of horse mackerel in the hauls from which the analysed specimen were taken. The scales were probably swallowed by the fish during their stay inside the trawl-net. A similar phenomenon has been described by Lipskaja (1972).

In the southern part of the examined area, that is in the fishing grounds of the Ambrose Bay and Lüderitz, food consisted mainly of Euphausiacea and only sometimes of fish (Myctophidae) - no matter what the length of the fish was. More to the north in the region of the Cape Frio - Cunene River estuary, the basic food component was Copepoda $(59,2 \%)$ and then Euphausiacea (20.8\% of food mass) - Table 5*. We have similar picture when analysing for frequency of occurrence of each food component (Table 6). In northern parts exists a clear relationship between food composition and the length of examined specimen. Smaller fish (20.0-24.5 cm of length) were feeding mainly on Copepoda (95.2\% of stomach content), whereas Euphausiacea made only $2.5 \%$ of stomach content. In bigger fish $(25-48 \mathrm{~cm})$ the content of Copepoda in food decreased to $51 \%$, but at the same time the content of Euphausiacea increased up to $24.9 \%$. Fish was found only inside a stomach of one big.specimen of the horse mackerel whose length was $43.5 \mathrm{~cm}$. There were 21 well preserved fish from the Myctophidae family of 5-8 $\mathrm{cm}$ inside its stomach. The total mass of these fish was quite big $14.2 \mathrm{~g}$, and made $23.7 \%$ of stomach icontent for fish of 25-48 cm of length (Table 5), whereas fish frequency occurrence in food was inconspicuous - 1.4\%(Table 6).

Vyskrebencev (1970) and Lipskaja (1972) stated the existence of 24-hour feeding rhytm of the horse mackerel. According to them the feeding was very intensive at day time; whereas at night horse mackerel did not feed at all. Our studies also confirm the above mentioned observation (Table 7). Out of 51 examined fish caught at $04^{00}-07^{30}$ of local time 50 had their stomachs empty, the exception was the big specimen whose stomach was filled with fish. Index of filling of this stomach has been calculated separately and was 232.4 . Among 23 examined specimen caught between $07^{30}-10^{00}$ only 6 had their stomachs empty - stomachs of 17 specimen were filled in insignificant degree. Index of filling was only 7.1. But, on the contrary, all fish caught from $10^{30}-13^{00}$ had their stomachs full, the filling index was 84.5 .

\footnotetext{
*Scales, sand and other contaminants may be not regarded as food so, were not counted when calculating the percentage of food composition
} 
Stomachs' content. composition of the horse-mackerel from different areas of the Namibian shelf. Percentage is given within the brackets.

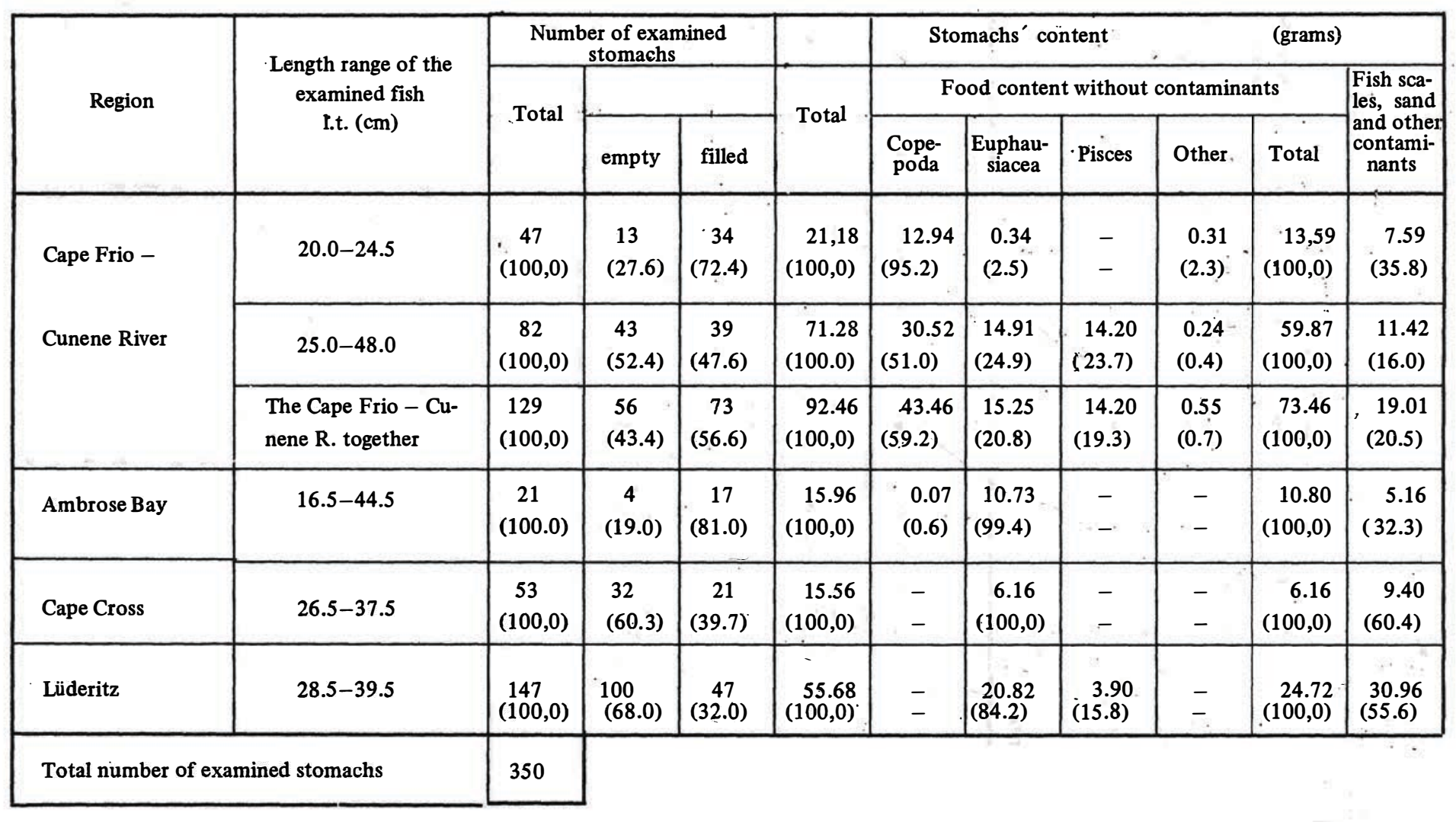


Frequency of occurence of particular food omponents in stomachs of the horse-mackerel Table 6. in different areas of the Namibian shelf. In \% of stomachs filled with food content

\begin{tabular}{|l|c|c|c|c|c|c|}
\hline & \multicolumn{7}{|c|}{ Food components } \\
\cline { 2 - 7 } & $\begin{array}{c}\text { Euphau- } \\
\text { siacea }\end{array}$ & Copepoda & Pisces & Pteropoda & $\begin{array}{c}\text { Crustacea } \\
\text { larvae }\end{array}$ & $\begin{array}{c}\text { Chaeto- } \\
\text { gnatha }\end{array}$ \\
\hline $\begin{array}{l}\text { Cape Frio - } \\
\text { Cunene River }\end{array}$ & 28.8 & 87.7 & 1.4 & 13.7 & 28.8 & 1.4 \\
\hline Ambrose Bay & 100,0 & 17,6 & - & - & - & - \\
\hline Cape Cross & 100,0 & - & - & - & - & - \\
\hline Ludderitz & 97.9 & - & 6.4 & - & - & - \\
\hline
\end{tabular}

Feeding intensity of the horse-mackerel in different time of day and night.

The Cape Frio - Cunene River area. The first decade of October 1973.

\begin{tabular}{|c|c|c|c|c|}
\hline \multirow{2}{*}{$\begin{array}{c}\text { Hours according } \\
\text { to the local time }\end{array}$} & \multirow{2}{*}{$\begin{array}{c}\text { Number of examined } \\
\text { stomachs }\end{array}$} & \multicolumn{2}{|c|}{$\begin{array}{c}\text { Average index } \\
\text { of filling* }\end{array}$} \\
\cline { 3 - 5 } & 51 & empty & filled & \\
\hline $4^{00}-7^{30}$ & 23 & 50 & 1 & 0.0 \\
\hline $7^{30}-10^{00}$ & 55 & 6 & 17 & 7.1 \\
\hline $10^{30}-13^{30}$ & & - & 55 & 81.5 \\
\hline
\end{tabular}

Explanation

$*$ Index of filling $=\frac{\text { food mass } \cdot 10^{4}}{\text { fish mass without intenstines }}$

** Index of filling calculated separately for one fish with stomach filled is given within the brackets.

\section{REFERENCES}

AtlantNIRO, 1974: Research report on investigation conducted by the USSR in the ICSEAF area. ICSEAF. Collection of Scientific Papers 1: 64-77.

Beverton R.J.H., Holt S.J., 1957: On the dynamics of exploited fish populations. London.

Belan R.A., 1971: Metodika opredelenija vozrasta juznoafrikanskoj stavridy (Trachurs trachurus capensis Castelnau) po otolitam. AtlantNIRO - Trudy, vyp. 4I: 53-60.

Davies D.H., 1957: The biology of the South African pilchard (Sardinops ocellata). Department of Commerce and Industries. Investigational Report no 32.

Gulland J.A., 1969: Manual of methods for fish stock assesment. Part. I. Fish population analysis. FAO Manuals in Fisheries Science No 4, Rome. 
Komarov J.A., 1964: Niekotoryje dannyje o rozmnoźenii stavridy Trachurus trachurus $L$. iz rejona jugo-zapadnogo pobierezja Afriki. Trudy AtlantNIRO, vyp. 11:87-99.

Komarov J.A., 1971: K opredieleniju jedinic zapasa juznoafrikanskoj stavridy (Trachurus trachurus capensis Castelnau). AtlantNIRO - Trudy, vyp. 41: 33-42.

Lipskaja N.J., 1972: Nekotoryje dannyje o rostie i pitanii stavridy - Trachurus trachurus Linne u zapadnogo pobierezja Afriki. Trudy VNIRO, 77, vyp. 2: 186-196.

Marecos M.L., 1974: Preliminary report on age and growth of the Cunene horse-mackerel (Trachurus trachurus trecae Cadenat) in Angola. ICSEAF, Coll. Sc. Pap., vol. I: 117-123.

Ricker W.E., 1958: Handbook of computations for biological statistics of fish populations. Fish. Res. Board Canada Bull. No 119, Ottawa.

Vyskrebencev B.V., 1970: Niekotoryje voprosy biologii stavridy Trachurus trachurus capensis C. jugo-zapadnogo pobierezja Afriki. Trudy AzcerNIRO, vyp. 29: 168-176.

Translated: mgr Danuta Przyłucka

Andrzej Kompowski, Wiesław S̊lósarczyk

\section{BIOLOGICZNA CHARAKTERYSTYKA POLSKICH POLOWÓW OSTROBOKA POSPOLITEGO - TRACHURUS TRACHURUS CAPENSIS CASTELNAU, 1861 W REJONIE SZELFU POLUDNIOWO-ZACHODNIEJ AFRYKI}

\section{Streszczenie}

Największe wydajności połowów ostroboka zanotowano w okresie od lipca do początku października w rejonie Ambrose Bay oraz dalej na północ aź do ujścia rzeki Cunene. Koncentracje ostroboków w tym rejonie składały się błdź z ryb już wytartych lub z gonadami w stadium spoczynkowym (Cape Cross i Lüderitz Bay), bądź w rejonach leżących bardziej na północ, prawie wyłącznie $z$ ryb w stadium spoczynkowym, ze znaczn̨ domieszkq osobników juwenalnych (Ambrose Bay) i miały charakter koncentracji żerowiskowych.

Parametry równania wzrostu $\left(L_{\infty}=46.99 \mathrm{~cm} ; t_{o}=0,1837\right.$ roku; $K=0,2498$ wskazuja na wysokie tempo wzrostu ostroboka $z$ badanego rejonu.

Współczynnik śmiertelności całkowitej (z) przyjmuje wartości 0,82 lub 0,9, zależnie od przyjętego sposobu obliczen. Przy założonym współczynniku śmiertelności naturalnej (M) wahajqcym się od 0,25 do 0,5, współczynnik śmiertelności połowowej (F) uzyskuje wysokq wartość, mieszcząca się odpowiednio w granicach od 0,32 do 0,65 , w zaleiności od założonego $M$.

Długość poławianych ostroboków zmieniała się w sposób istótny w zależności od rejonu połowów. Na łowiskach położonych bardziej na południe dominowały ryby większe niż na łowiskach północnych. Niemałą rolę mogła tu odegrać głębokość trałowania, która była większa na połudhiu. Jest bowiem rzecz znang, że ryby młodsze, o mniejszych rozmiarach, trzymają się wód płytszych, położonych bliżej brzegu. Stwierdzono jednak, że wartości modalne długości, niezależnie od miejsca połowów zmieniały się nieznacznie, co świadczy o wyrównanym tempie wzrostu ostroboków w całym badanym rejonie.

Stwierdzono istnienie zależności między temperaturą wody a występowaniem skupisk ostroboka. Wyraźną zależność uzyskano dla łowiska Ambrose Bay, gdzie najwyższe wydajności połowowe ostroboka uzyskiwano przy temperaturze $11,7^{\circ}$ i $12,8^{\circ} \mathrm{C}$.

Ostrobok $z$ omawianego rejonu odżywiał się głównie planktonowymi Copepoda oraz Euphausiacea, a w mniejszym stopniu rybami $z$ rodziny Myctophidae. Intensywność żerowania była najwię ksza w porze dziennej, co podkreślają równiez badania innych autorów. 


\section{БИОЛОГИЧЕСКАЯ ХАРАКТЕРИСТИКА СТАВРИДЫ ОБЫКНОВЕННОЙ TRACHURUS TRACHURUS CAPENSIS CASTELINAU, 1861 \\ ИЗ УЛОВОВ ПОЛЬСКИХ СУДОВ, ПРОМЫШЯющИХ \\ В РАЙОНЕ ШЕЛЬФОВ ЮГО-ЗАПАДНОЙ АФРИКИ}

$$
P \text { e }
$$

Самая высокая производительность лова ставриды отмечалась в период с июля до начала октября в районе Ambrose Bay и далее на север, вплоть до устья реки Кунене. Скопления ставриды в этом районе состояли либо из уже отнерестившейся рыбы, или из рыбы с тонадами в латентной стадии (м. Кросс и Людериц-Бей), либо же, в более северных районах, почти полностью из рыбы в латентной стадии со значительным, однако, количеством (Ambrose Bay) ювенальных особей и носили нагульный характер.

Параметры уравнения роста ( $\mathrm{I}=46,99 \mathrm{~cm} ; t_{0}=0,1837$ года; $\mathrm{K}=02498$ ) свидетельствует о высоком темпе роста ставриды в ұсследуемом районе. КоэФфйицент полной смертности равен $=0,82$ или $=0,9$ в зависимости от применяемото способа вычислений. При условном коэбфбиценте естественной смертности $(\mathbb{M})$, колебющемся от 0,25 до 0,5, коэфо̆ициент промысловой смертности (F) приобретает большие величины, а именно от 0,32 до 0,65 в зависимости от величины М.

Длина промысловой ставриды изменялась существенным образом в зависимости от района лова. В промысловых районах, расположенных южнее, преобладала более крупная рыба, чем в северных районах лова. Немалую роль могла 'здесь сыграть глубина траления, которая была большей на юге. Общеизвестно, что рыба младшего возраста и, следовательно, меньших размеров держится на более мелких, расположенных ближе к берегу местах. Установлено, однако, что модальные величины длины независимо от места промысла изменялись незначительным образ́ом, что всидетельствует о равномерном темпе роста ставриды во всём исследуемом районе.

Установлена также зависимость между температурой воды и появлением скоплений ставриды. Определена чёткая зависимость для района лова пде самая высокая промысловая производительность ставриды отмечена при темлературе $11,7^{\circ} \mathrm{C}$ й $12,8^{\circ} \mathrm{C}$.

Ставрида в исследуемом районе питается главным образом планктонным организмами Copepoda и Euphausiacea, и в меньшей мере рыбой из семейства Inctophidae. Самая высокая интенсивность питания отмечена в дневное вреия, на что указывают такле исследования других авторов.

Address:

Received: 3 X 1975 r.

Dr Andrzej Kompowski

Instytut Ichtiologii AR

71-550 Szczecin, ul. Kazimierza Królewicza 4

Polska - Poland 